\title{
Nucleoside Analogs and Nucleoside Precursors as Drugs in the Fight against SARS-CoV-2 and Other Coronaviruses
}

\author{
Nicola Borbone ${ }^{1}\left(\right.$, Gennaro Piccialli ${ }^{1}$, Giovanni Nicola Roviello ${ }^{2, *} \mathbb{C}$ and Giorgia Oliviero ${ }^{3}(\mathbb{C}$ \\ 1 Department of Pharmacy, University of Naples Federico II, Via Domenico Montesano 49, 80131 Naples, Italy; \\ nicola.borbone@unina.it (N.B.); picciall@unina.it (G.P.) \\ 2 Institute of Biostructures and Bioimaging-CNR 1, Via Mezzocannone 16, 80134 Naples, Italy \\ 3 Department of Molecular Medicine and Medical Biotechnologies, University of Napoli Federico II, \\ Via Sergio Pansini 5, 80131 Naples, Italy; golivier@unina.it \\ * Correspondence: giroviel@unina.it; Tel.: +39-081-253-4585
}

Citation: Borbone, N.; Piccialli, G.; Roviello, G.N.; Oliviero, G.

Nucleoside Analogs and Nucleoside Precursors as Drugs in the Fight against SARS-CoV-2 and Other Coronaviruses. Molecules 2021, 26, 986. https://doi.org/10.3390/ molecules26040986

Academic Editor: Ramon Eritja

Received: 14 December 2020

Accepted: 10 February 2021

Published: 13 February 2021

Publisher's Note: MDPI stays neutral with regard to jurisdictional claims in published maps and institutional affiliations.

Copyright: (c) 2021 by the authors. Licensee MDPI, Basel, Switzerland. This article is an open access article distributed under the terms and conditions of the Creative Commons Attribution (CC BY) license (https:/ / creativecommons.org/licenses/by/ $4.0 /)$.

\begin{abstract}
Coronaviruses (CoVs) are positive-sense RNA enveloped viruses, members of the family Coronaviridae, that cause infections in a broad range of mammals including humans. Several $\mathrm{CoV}$ species lead to mild upper respiratory infections typically associated with common colds. However, three human $\mathrm{CoV}(\mathrm{HCoV})$ species: Severe Acute Respiratory Syndrome (SARS)-CoV-1, Middle East Respiratory Syndrome (MERS)-CoV, and SARS-CoV-2, are responsible for severe respiratory diseases at the origin of two recent epidemics (SARS and MERS), and of the current COronaVIrus Disease 19 (COVID-19), respectively. The easily transmissible SARS-CoV-2, emerging at the end of 2019 in China, spread rapidly worldwide, leading the World Health Organization (WHO) to declare COVID-19 a pandemic. While the world waits for mass vaccination, there is an urgent need for effective drugs as short-term weapons to combat the SARS-CoV-2 infection. In this context, the drug repurposing approach is a strategy able to guarantee positive results rapidly. In this regard, it is well known that several nucleoside-mimicking analogs and nucleoside precursors may inhibit the growth of viruses providing effective therapies for several viral diseases, including $\mathrm{HCoV}$ infections. Therefore, this review will focus on synthetic nucleosides and nucleoside precursors active against different $\mathrm{HCoV}$ species, paying great attention to SARS-CoV-2. This work covers progress made in anti-CoV therapy with nucleoside derivatives and provides insight into their main mechanisms of action.
\end{abstract}

Keywords: coronavirus; SARS-CoV-1; SARS-CoV-2; MERS-CoV; nucleoside drugs; remdesivir; ribavirin; favipiravir; molnupiravir; sofosbuvir

\section{Introduction}

Coronaviruses (CoVs) are enveloped positive-sense single-stranded RNA viruses belonging to the family Coronaviridae, causing infections in avian species, mammals, and, among these, humans [1-6]. Human coronaviruses (HCoV) are believed to be of zoonotic origin, and their infections mainly lead to respiratory diseases [7-9]. In particular, HCoV229E, HCoV-OC43, HCoV-NL63, and HCoV-HKU1 cause the mild seasonal symptoms of the common cold $[10,11]$. However, three $\mathrm{HCoV}$ species responsible for the onset of lifethreatening respiratory events emerged in the last two decades: Severe Acute Respiratory Syndrome (SARS)-CoV-1, Middle East Respiratory Syndrome (MERS)-CoV, and SARS-CoV2 [12-15]. Human infection by SARS-CoV-2 is at the origin of the current COronaVIrus Disease 19 (COVID-19) pandemic. Interestingly, SARS-CoV-1 and MERS-CoV are more lethal but less transmissible than SARS-CoV-2, to which they are closely related [16]. There is clearly an urgent need for mass immunization and specific treatments for these $\mathrm{HCoV}$-associated pathologies. CoV infection starts with the specific molecular recognition between the CoV spike (S) protein and host-specific receptors exposed on the surface of the target cells [17-21]. These have been identified for several CoVs and represent the primary molecular targets for anti-CoV strategies [22]. Human aminopeptidase $\mathrm{N}$ 
(APN) is involved in the infection by HCoV-229E; 9-O-acetylated sialic acid (9-O-Ac-Sia) receptor for $\mathrm{HCoV}-\mathrm{OC} 43$ and $\mathrm{HCoV}-\mathrm{HKU} 1$; angiotensin-converting enzyme 2 (ACE2) for HCoV-NL63, SARS-CoV-1, and SARS-CoV-2; dipeptidyl peptidase 4 (DPP4) for MERS$\mathrm{CoV}[23,24]$. Intracellularly, CoVs replicate their RNA and produce the viral proteins required for the assembly of new viral particles [25]. While five out of the seven HCoVs are usually associated with mild upper respiratory infections, MERS-CoV and SARSCoV-1 and 2 can lead to lethal events [26]. In particular, the new SARS-CoV-2, first emerging in China at the end of 2019 [26], can provoke severe pneumonia, and being easily transmissible, it rapidly spread worldwide leading the World Health Organization (WHO) to declare COVID-19 a pandemic in March 2020 [27]. Currently, there have been more than two million deaths due to COVID-19 (2,239,418 as found in Worldometers.info [28] accessed on 1 February 2021), with enormous consequences for public health and the global economy [29-31]. While the whole world is fighting against COVID-19 and waits for a global and effective vaccination, the scientific community is devoting immense efforts to develop effective drugs for the immediate treatment of SARS-CoV-2 infection. Due to the urgent need for such a pharmacological treatment, drug repurposing $[32,33]$ is one of the most common approaches. In this context, nucleobase-containing synthetic molecules [34-40] and modified nucleosides [41-46] are attracting significant interest for their antiviral activity [47-49]. In particular, nucleoside-mimicking analogs [50], as well as nucleoside precursors [51,52], being able to inhibit the growth of viruses, play a pivotal role in the search of effective therapies for $\mathrm{HCoV}$ infectious diseases [53,54].

\section{Human Coronaviruses}

Presently, seven HCoVs are known and described in the scientific literature [55]. Besides the well-known potentially lethal SARS-CoV-1, MERS-CoV, and SARS-CoV-2, the common human coronaviruses HCoV-229E, HCoV-NL63, HCoV-OC43, and HCoV-HKU1 identified in the last few decades were classified into two $\mathrm{CoV}$ genera: Alphacoronavirus and Betacoronavirus [56].

HCoV-229E and HCoV-NL63, belonging to the genus Alphacoronavirus [57], are genetically related to each other and are responsible for about $5 \%$ of all respiratory infections in hospitalized children [58]. Both HCoV-OC43 and HCoV-HKU1, of the genus Betacoronavirus [59], are 'common cold' viruses widely circulating worldwide, with associated severity of respiratory symptoms being documented only in rare cases [60]. Even though these $\mathrm{HCoVs}$ do not cause severe clinical symptoms in most patients, $\mathrm{HCoV} 229 \mathrm{E}$ and OC43 can provoke pneumonia [61,62], while HCoV-NL63 and HCoV-HKU1 infection lead in some cases also to bronchiolitis and croup [63,64].

\section{Human Coronaviruses Causing Lethal Pneumonia: SARS-CoV-1, MERS-CoV, and SARS-CoV-2}

The first HCoV-recognized pandemic, known as 'Severe Acute Respiratory Syndrome' (SARS), was caused by SARS-CoV-1 in China in 2002-2003 [65,66]. It spread to 29 countries worldwide, infecting over 8,000 people, with a 10\% death rate [67]. Another deadly coronavirus emerged about ten years later, leading to the so-called 'Middle East Respiratory Syndrome' (MERS) and was indicated, thus, MERS-CoV [68]. After its outbreak in Jordan among hospital workers, it spread to Saudi Arabia in 2013-2014 [69]. MERS occurs predominantly in male individuals, while the same is not seen for SARS. The main clinical symptoms of both SARS and MERS include fever, cough, shortness of breath, and respiratory illness, with MERS being associated with more severe pneumonia and a higher mortality rate of up to $35 \%$ vs. the already-cited $10 \%$ of SARS [70]. Both MERS and SARS affect mainly adult individuals with a median age range of 39-50 years [62]. SARS-CoV-2 is closely related to SARS-CoV- 1 , with which it shares about $79 \%$ genome sequence identity, and is responsible for the current COVID-19 [71].

Like SARS-CoV-1 and MERS-CoV, SARS-CoV-2 belongs to the genus Betacoronavirus, but while the two SARS-CoVs are further classified into the Sarbecovirus subgenus, MERS$\mathrm{CoV}$ belongs to the Merbecovirus subgenus [72]. Globally, the WHO estimated a mortality 
rate due to COVID-19 of 3.4\%, though there is no definitive consensus on this estimate [73]. Whatever the mortality rate of SARS-CoV-2, one of the most worrying aspects of this virus is that it spreads easily and rapidly, having reached in a few months hundreds of countries infecting more than 100 million individuals.

\section{Prophylaxis and Therapy of HCoV Diseases}

Before 2002, the only known HCoVs were the common human coronaviruses associated with 'common cold' symptoms mentioned above. Since most people with an illness caused by them usually recovered spontaneously, there was typically no need for any drugs other than aspirin to relieve the cold-associated symptoms. Conversely, the critical clinical conditions often observed in patients affected by the highly pathogenic MERS-CoV, SARS-CoV-1, and, especially, SARS-CoV-2 recalled the urgency of developing vaccines and antiviral treatments for $\mathrm{HCoV}$ infections. This research theme was previously almost ignored by pharmaceutical companies and, in our opinion, should not be abandoned by the scientific community even when the COVID-19 emergency will be over. In SARS-CoV-1 infection, scientists undertook initial vaccine studies, but the obtained candidates presented severe complications such as immune disease insurgence in treated animals [74]. The research for other SARS vaccines was discontinued not only for the difficulties encountered, but mainly because SARS-CoV-1 vanished [74]. Owing to the pharmacological strategies adopted by physicians for SARS patients, these were essentially empirical and involved repurposed immunomodulatory and antiviral drugs, such as corticosteroids, lopinavir/ritonavir, and ribavirin [32,33]. Concerning MERS, despite several efforts to search for effective vaccines, antibodies, and drugs, no conclusive results were achieved. Repurposed drugs used with some success for MERS include again lopinavir/ritonavir and ribavirin [75,76]. After this premise, it appears clear how the lack of any useful vaccine and drug against SARS-CoV-1 and MERS-CoV was reflected in the current crisis, considering the relatively close relationship between SARS-CoV-1 and SARS-CoV-2 genomes, as well as the conserved nature of MERS and SARS-CoV-2 proteins [71]. Fortunately, academic institutions and pharmaceutical companies have lately developed some promising vaccine candidates against SARS-CoV-2. Among them, the Pfizer-BioNTech (BNT162b2) [77], the Moderna (mRNA-1273) [78], and the Oxford University / AstraZeneca (ChAdOx1-S) [79] vaccines were authorized for prophylaxis of COVID-19, while several others are currently in late-stage clinical testing [80]. Vaccines may represent a medium/long-term solution to the current pandemic, but short-term solutions such as pharmacological treatments against SARS-CoV-2 remain urgently needed. Presently, SARS-CoV-2 infection therapy includes immunomodulatory drugs, plasma from individuals recovered from COVID-19, and several pharmacological treatments [81]. In this regard, despite numerous repurposed drugs being tested, only the nucleoside analog remdesivir has been officially approved by the American Food and Drug Administration (FDA) agency to date [82].

\section{Protein Targets for Anti-HCoV Pharmaceutical Strategies}

Amongst the coronavirus targets that were studied, or are currently being investigated, in the fight against the three most pathogenic $\mathrm{HCoVs}$, particular relevance is given to the spike (S) protein [17-21], RNA-dependent RNA-polymerase (RdRp) [83-87], papain-like protease (PL $\left.{ }^{\text {pro }}\right)[88,89]$ and main protease (Mpro, 3CL $\left.{ }^{\text {pro }}\right)[90,91]$. In particular, this latter, which proteolytically cleaves the polyproteins to functional proteins essential for viral replication, occupies a special place in pharmaceutical research [92]. Hence, the frequentlyreported administration of potential Mpro inhibitors like lopinavir and ritonavir to SARS, MERS, and COVID patients [76,93,94], even though there is no agreement on the real efficacy of this cocktail therapy, especially in the case of the current pandemic [94]. RdRp is a protein involved in SARS-CoV-2 replication, considered to be conserved within RNA viruses [95]. Targeting the RdRp by antiviral drugs could be a potential therapeutic option to inhibit coronavirus RNA polymerization and, consequently, viral replication. Since remdesivir [82], the only FDA-approved drug for COVID-19 available to date, is believed 
to inhibit SARS-CoV-2 RNA polymerase competing with natural nucleotide triphosphates for incorporation into growing viral RNA, this aspect attracts interest not only on this drug but also on other analogs of nucleosides and nucleoside precursors with similar RdRp inhibitory activity.

\section{Synthetic Nucleoside Precursors for HCoV Disease Therapy}

Among the synthetic drugs under scrutiny in the treatment of viral respiratory pathologies, nucleoside precursors occupy an important place, especially in the present COVID-19 pandemic [54]. Here below, we report on the main nucleoside precursors evaluated as anti-HCoV drugs (Figure 1).<smiles>NC(=O)c1nc(F)c[nH]c1=O</smiles>

5-fluoro-2-oxo-1H-pyrazine-3-carboxamide favipiravir<smiles>CCS(=O)(=O)N1CC(CC#N)(n2cc(-c3ncnc4[nH]ccc34)cn2)C1</smiles>

2-[1-ethylsulfonyl-3-[4-(7H-pyrrolo[2,3-d]pyrimidin-4-yl) pyrazol-1-yl]azetidin-3-yl]acetonitrile

baricitinib

4<smiles>O=c1[nH]c(=O)c2cn[nH]c2[nH]1</smiles>

1,7-dihydropyrazolo[3,4-d]pyrimidine-4,6-dione oxypurinol 2<smiles>CN(Cc1cnc2nc(N)nc(N)c2n1)c1ccc(C(=O)N[C@@H](CCC(=O)O)C(=O)O)cc1</smiles>

Figure 1. Structures of the nucleoside precursors and derivatives of purine analogs (with drug names and related IUPAC nomenclature) used or under investigation in the $\mathrm{HCoV}$ disease therapy.

\subsection{Favipiravir}

Favipiravir (also indicated as T-705, 1, Figure 1) is an oral drug that inhibits the RdRp of a wide range of RNA viruses including influenza, rhinoviruses, and also non-respiratory RNA viruses [96,97]. Its use was previously approved for influenza in Japan and as an experimental drug for Ebola virus infection [98]. However, the recent interest paid to this drug originates from the reports of favipiravir efficacy in COVID-19 management.

Even though the matter is still controversial, its utility in prevention of pneumonia and SARS aggravation was suggested by randomized studies on COVID-19 patients treated with this safe and well-tolerated drug, who achieved SARS-CoV-2 viral clearance in $62.5 \%$ of cases within four days from the favipiravir treatment [99]. In another study, SARS-CoV2-positive patients in severe or critical conditions who were administered this drug for their deteriorating conditions were eventually cured [100].

Owing to its mechanism of action, intracellularly, 1 undergoes its hypoxanthineguanine phosphoribosyltransferase (HGPRT)-mediated conversion into mono-(1a) and, subsequently, triphosphoribosylated (1) form, which is recognized as a substrate by the 
viral RdRp, acting as a chain terminator and, thus, inhibiting the viral polymerase activity (Figure 2) [101].

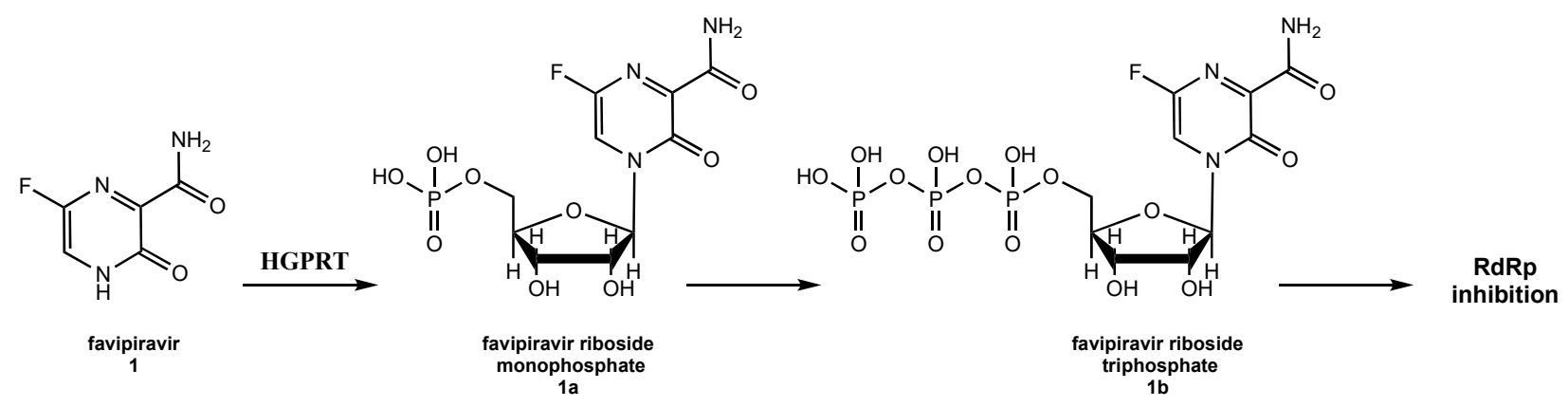

Figure 2. Mechanism of action of favipiravir.

\subsection{Oxypurinol}

Oxypurinol (also known as XORTX, 2, Figure 1) is an inhibitor of xanthine oxidase [102] that is known to be effective for decreasing the production of uric acid, an aspect relevant especially in medical conditions like gout and kidney stones, but also for preventing inflammatory responses [103,104]. Due to its potential preventive activity against the SARS hyperinflammatory response, oxypurinol was proposed in combination with pentoxifylline (3, Figure 1) to treat COVID-19 [105].

\subsection{Pentoxifylline}

Pentoxifylline (also referred to as oxpentifylline, 3, Figure 1), a synthetic nucleoside precursor structurally related to caffeine and theophylline, in combination with oxypurinol, is able to reduce the effects of experimentally-induced inflammation [106]. In fact, pentoxifylline inhibits the production of TNF- $\alpha$, a receptor that activates inflammatory genes such as IL-6, which regulates neutrophil infiltration into the interstitial lung tissue, causing severe injuries [105]. Since pentoxifylline may also exert its anti-inflammatory action in the hyperinflammatory phase in COVID-19 patients, it was hypothesized that early treatment of SARS-CoV-2-infected individuals with pentoxifylline, also combined with oxypurinol, could be a valid preventive anti-SARS treatment [105]. Both $\mathbf{2}$ and $\mathbf{3}$ are licensed drugs already in use for therapy of different diseases, and, consequently, this would avoid phase I clinical trials for their administration to COVID-19 patients [105].

\subsection{Derivatives of Purine Analogs}

Even if it cannot be properly considered a nucleoside precursor, baricitinib (the active ingredient of Olumiant drug, 4, Figure 1) is a purine derivative previously known as a Janus kinase inhibitor and approved for the treatment of rheumatoid arthritis [107]. It was recently used in COVID-19 therapy combined with remdesivir, but its effectiveness is still a matter of debate [108]. Moreover, methotrexate (5, Figure 1), a well-known anticancer and immune suppressant drug [109], was recently investigated as a potential anti-COVID-19 drug and proved effective in inhibiting the SARS-CoV-2 virus replication in vitro [110].

\section{Nucleoside Analogs as Anti-HCoV Drugs}

Nucleoside analogs are widely used as drugs against infections caused by herpes viruses, hepatitis B virus, human immunodeficiency virus (HIV) but also against RNA virus infections such as hepatitis $C$ [62]. The main advantages of nucleosides over nonnucleoside antiviral agents include their applicability to a broad-spectrum of viral strains or species and their ability to overcome the antiviral resistance [62]. This is due to the polymerase inhibitor mechanism of action common to the majority of nucleoside analogs used in the antiviral therapy and to the well-conserved nature of nucleotide-binding sites in polymerases among the different virus families [111]. In detail, intracellularly, most 
nucleoside analogs are converted by host kinases to their triphosphate forms, which compete with natural nucleoside triphosphates in binding to the viral polymerase active site, eventually impairing RNA or DNA synthesis [112]. Structurally, nucleoside polymerase inhibitors are both purinic and pyrimidinic synthetic derivatives in which the sugar or the nucleobase underwent chemical modification (Figure 3). Administered as nucleotide precursors, they are metabolized by kinase enzymes to the active triphosphate forms inside the host. The unnatural nucleotides are then incorporated into replicating viral genomes leading to chain termination and subsequent blockage of replication or transcription [112]. In another mechanism, nucleoside analogs are incorporated into elongating nucleotide chains, potentially leading to mutations that alter one or more fundamental viral processes such as RNA structuring, its interaction with proteins, viral protein functions, and RNA synthesis [113]. As mentioned, nucleoside analogs overcome the antiviral resistance because the binding site of their polymerase targets is highly conserved among virus families, with amino acid conservation percentages as high as $70-100 \%$ in the case of CoVs [113]. This highlights the importance of developing nucleoside analogs as anti-coronavirus drugs with RdRp inhibitory activity. Here below, we summarize the properties of some of the most relevant drugs belonging to this family of synthetic $\mathrm{HCoV}$ inhibitors (Figure 3).

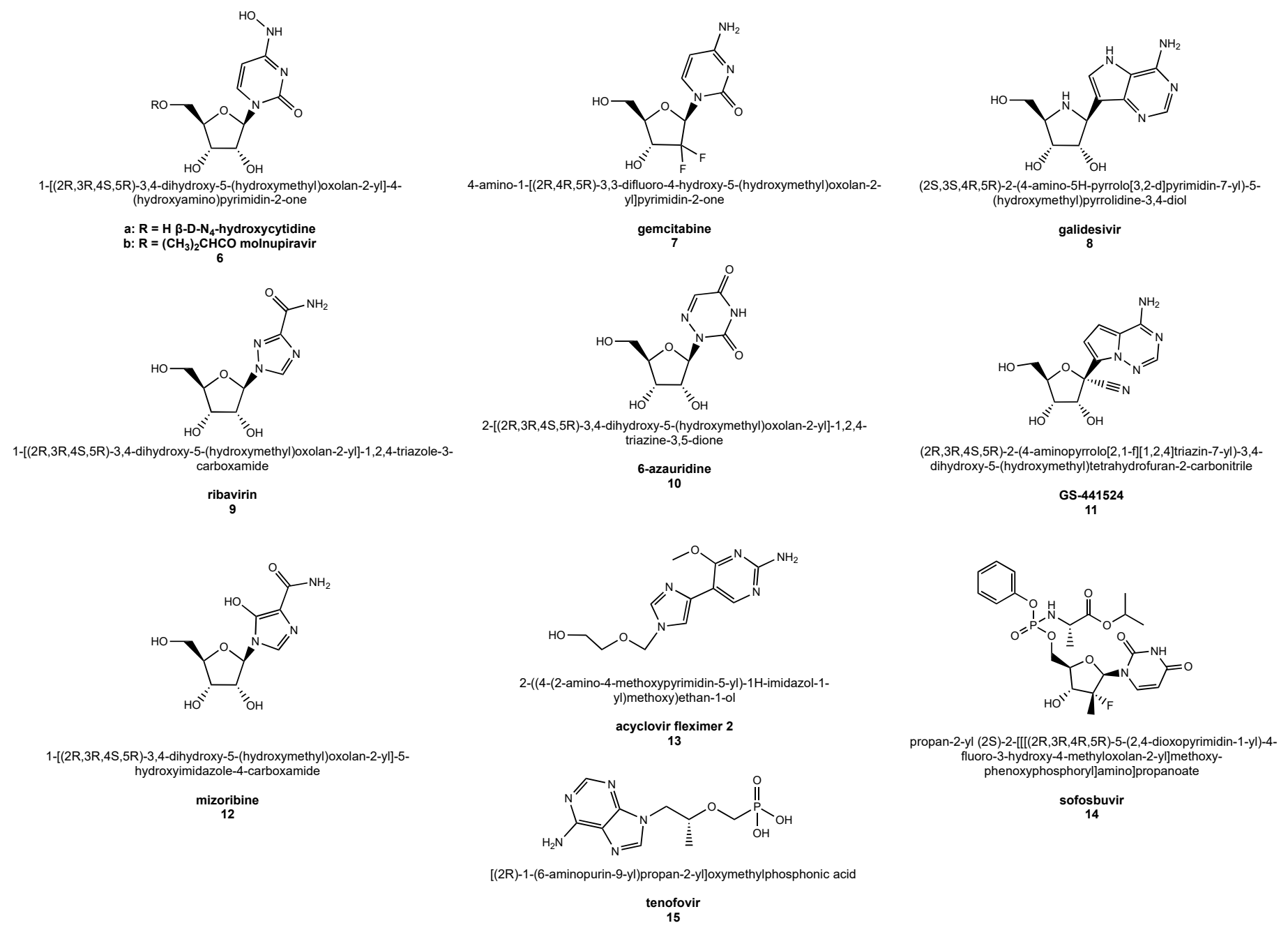

Figure 3. Structures of the nucleoside analogs (provided with drug names and related IUPAC nomenclature) used or under investigation in the $\mathrm{HCoV}$ disease therapy.

\section{1. $\beta$-D-N4-Hydroxycytidine}

$\beta$-D-N4-Hydroxycytidine (NHC, 6a, Figure 3) is a cytidine analog with broad-spectrum 
antiviral activity as found with influenza A and B viruses, respiratory syncytial virus, Venezuelan equine encephalitis virus, zoonotic group $2 b$ or $2 c$ bat-CoVs [114], and HCoVs [115]. This drug's mechanism of action is based on NHC-triggered mutagenesis of viral RNA and, as found in the case of $\mathrm{HCoVs}$, on its interaction with viral replicase. NHC showed potent antiviral activity against the coronaviruses HCoV-NL63 and, more interestingly, SARS-CoV-1 [115]. In vitro studies also demonstrated the ability of NHC to inhibit MERS-CoV with minimal cytotoxicity [116], and its applicability was also proposed for COVID-19 therapy [114].

\subsection{Molnupiravir}

Molnupiravir (also known as MK-4482 and EIDD-2801, 6b, Figure 3) is a prodrug of $6 \mathbf{a}$ active as an antiviral drug against influenza [117]. This nucleoside analog blocked SARS-CoV-2 transmission in animal models [118] and was used in one-year stage II/III trial on hospitalized COVID-19 patients [119].

\subsection{Gemcitabine}

Gemcitabine (7, Figure 3) is a deoxycytidine analog with a broad-spectrum antiviral activity that inhibits SARS-CoV-1 and MERS-CoV [120]. Gemcitabine potential as an anti-COVID-19 drug was recently investigated in cell culture [121]. This nucleoside analog inhibited SARS-CoV-2 replication in infected Vero-E6 cells at noncytotoxic drug concentrations [121]. In the same study, cytidine nucleoside suppressed the gemcitabine antiviral effect while, combined administration of gemcitabine with oxysophoridine led to an additive antiviral effect against the coronavirus [121].

\subsection{Galidesivir}

Galidesivir (also known as BCX4430 or Immucillin-A, 8, Figure 3) is an adenosine analog with broad antiviral activity against several RNA viruses and low cytotoxicity [122]. In vitro, 8 exerts antiviral activity against pathogenic $\mathrm{HCoVs}$ with coronavirus inhibition observed in cells infected with SARS-CoV-1 and MERS-CoV [122]. At the same time, in silico, 8 shows potent activity against SARS-CoV-2 due to its tight binding to the $\mathrm{HCoV}$ $\operatorname{RdRp}[123]$.

\subsection{Ribavirin}

Ribavirin (9, Figure 3), also referred to as Virazole or ICN 1229, is an analog of guanosine used as a broad-spectrum antiviral drug against infections of different RNA viruses, including hepatitis $\mathrm{C}$ virus (HCV), hantavirus, and respiratory syncytial virus $[124,125]$. Two main mechanisms for its antiviral action were described involving the drug in monophosphate and triphosphate form, respectively. The first form interacting with the host nucleotide-synthesizing enzyme IMPDH (inosine monophosphate dehydrogenase) lowers the guanosine production levels with consequent inhibition of viral RNA synthesis [124]. In the second mechanism, ribavirin triphosphate incorporated by the viral polymerase provokes lethal mutagenesis [124]. However, the coronavirus exonuclease proofreading activity shields $\mathrm{HCoVs}$ from ribavirin antiviral action, even using drug doses that proved active against other RNA viruses [113]. Interestingly, at high doses, this guanosine analog partially inhibited in vitro replication of MERS-CoV and SARS-CoV-1, leading, however, to disease worsening in animal models of SARS-CoV-1 infection [113]. Remarkably, no significant clinical benefit was revealed in patients affected by SARS who experienced even drug toxicity [113]. Though the combined treatment with well-tolerated doses of ribavirin and interferon IFN $\alpha 2 b$ resulted in an increased therapeutic effect of the nucleoside drug, in both in vitro and animal models of MERS-CoV disease [126], when the same approach was applied to human subjects with critical MERS-CoV infection, no efficacy was recorded [113]. Moreover, survival was not improved in MERS patients receiving 9 with both interferons IFN $\alpha 2 \mathrm{a}$ and IFN $\beta 1$ [ [113]. Ribavirin found interest in the experimental therapy of COVID-19, also in combination with other antiviral agents and interferon 
IFN $\beta 1 b$ [76], following evidence of its in vitro efficacy on SARS-CoV-2 [75]. However, although this guanosine analog shows anti-HCoV efficacy in vitro, there is no agreement on its clinical benefit to patients with SARS-CoV-1, SARS-CoV-2, or MERS-CoV infections.

\subsection{6-Azauridine}

The uridine analog 6-azauridine (10, Figure 3 ) is endowed with orotidine monophosphate decarboxylase inhibitory activity and consequent antiviral effect [127]. It was effective against HCoV-NL63 at the early stages of HCoV replication [128] and inhibited replication of SARS-CoV-1 at non-toxic doses [127]. Although no experimental data on its effect on SARS-CoV-2 are currently available, this nucleoside analog is among the drugs to be considered for COVID-19 treatment [129].

\subsection{GS-441524}

Gilead Science (GS)-441524 (11, Figure 3) is a 1'-cyano adenosine analog, which is the main plasma metabolite of the more famous antiviral drug remdesivir (GS-5734, Figure 4) [130]. Several cellular studies conducted on 11 indicated an anti-SARS-CoV-2 activity comparable when not higher than remdesivir [131], with some studies pointing out that 11 would be even more convenient than remdesivir for the COVID-19 therapy [131]. GS-441524 advantages over remdesivir include ease of synthetic preparation, lower hepatic toxicity, as well as oral administration route (not suitable for remdesivir due to its poor liver stability) [131].

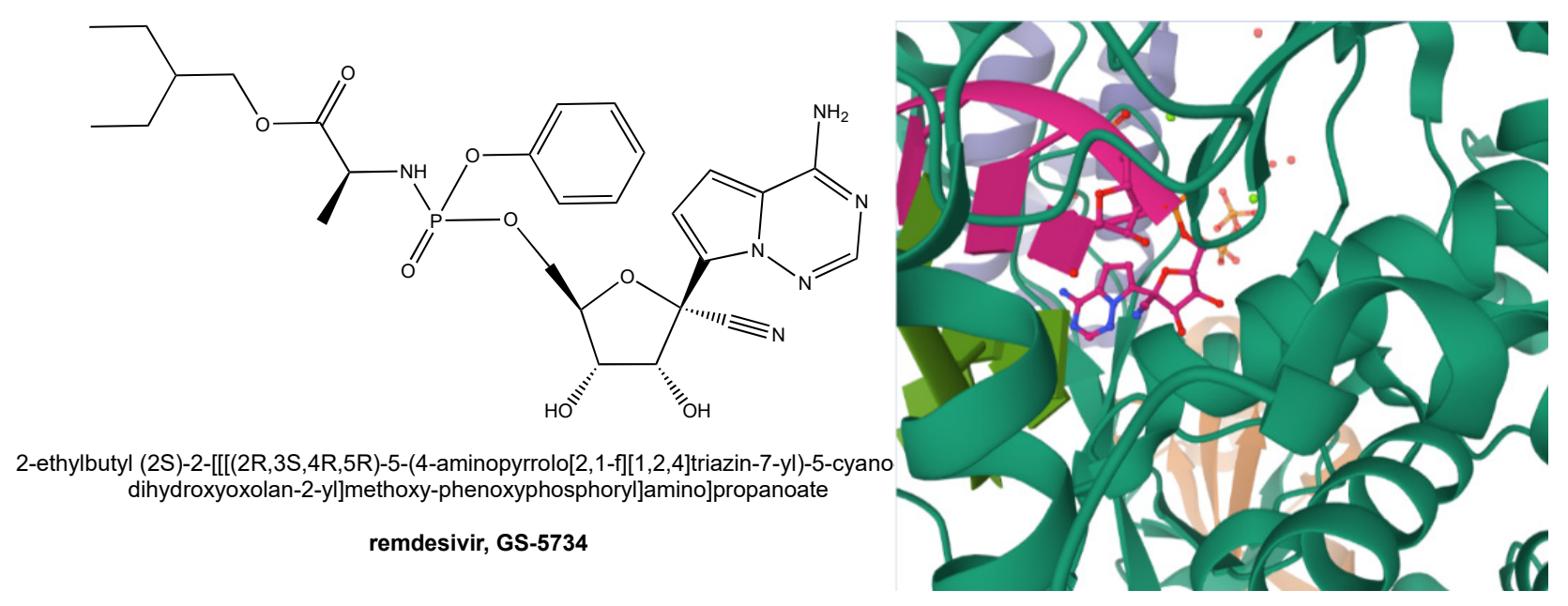

Figure 4. Structural representation of remdesivir (with use and IUPAC names, left) and view of its triphosphate form bound to SARS-CoV-2 RdRp in the active site (PDB ID: 7BV2 [132], image obtained using Mol* [133], https://www.rcsb.org/3dview /7BV2 (accessed on 10 December 2020), right).

\subsection{Mizoribine}

Mizoribine (also known as MZB, 12, Figure 3) is an imidazole nucleoside with known inosine-5'-monophosphate dehydrogenase inhibitory activity [134]. Mizoribine inhibited the replication of SARS-CoV-1 more effectively than ribavirin, but it could not completely inhibit the replication of the virus even at concentrations up to $100 \mu \mathrm{g} / \mathrm{mL}$ [135]. As an inhibitor of the proinflammatory protein HSP60, 12 was recently identified as an already clinically approved drug able to potentially ameliorate severe inflammatory reaction in COVID-19 patients [136].

\subsection{Acyclovir Fleximer 2}

A flexible-base modification of the guanosine analog acyclovir (herein indicated as acyclovir fleximer 2, 13, Figure 3) showed activity against HCoV-NL63 in cellular studies [137]. The same derivative could block the replication of the highly pathogenic 
MERS-CoV but not SARS-CoV-1, while unmodified acyclovir had no effect under the same experimental conditions [137]. In our opinion, this compound and the entire family of acyclovir fleximers merit further investigational efforts in the fight against COVID-19.

\subsection{Nucleotide Drugs: Sofosbuvir and Tenofovir}

Sofosbuvir (14, Figure 3) is a nucleotide analog used to treat HCV infection, which can inhibit the SARS-CoV-1 RNA-dependent RNA polymerase [138], affecting the viral life cycle, as underlined in the study of Li and De Clercq [139]. Together with the acyclic nucleotide phosphonate (ANP) tenofovir (15, Figure 3) [140], sofosbuvir was predicted to bind the SARS-CoV-2 RdRp tightly, blocking the viral life cycle at the stage of nucleotide incorporation [140]. This mechanism was experimentally proven by Chien et al., who demonstrated that SARS-CoV-2 RdRp can incorporate the triphosphate forms of sofosbuvir and tenofovir, thus blocking the incorporation of further nucleotide triphosphates [141]. On the other hand, the studies performed by the group of Schinazi showed no antiviral effect for sofosbuvir against SARS-CoV-2 [142]. In contrast, a randomized controlled trial on COVID-19 patients showed that adding this drug to standard care significantly reduced hospital stay duration but did not have any statistically-significant benefit on mortality [143]. In regard to tenofovir, no published data from randomized trials are presently available, and only a few clues of its protective role against SARS-CoV-2 infection emerged by a preliminary clinical study [144].

$\mathrm{RdRp}$ represents the main target of anti-HCoV nucleoside drugs. Though the alignment of the amino acid sequences of the RdRp found in the three highly pathogenic coronaviruses revealed high homology and conservation rates, in close analogy with other positive-sense RNA viruses (like HCV [145]), among HCoVs SARS-CoV-2 RdRp shares 96\% homology with SARS-CoV-1 RdRp, but only 70\% with MERS-CoV RdRp [146]. MERS RdRp structure has not yet been solved experimentally. Still, attempts were made to describe it computationally [147]. The results suggested that, despite the lower overall homology levels of MERS-CoV RdRp, its active site is still highly conserved within the positive-sense RNA viruses. Therefore, HCV RdRp inhibitors may also be effective inhibitors of MERSCoV RdRp [147]. On this basis, sofosbuvir, developed as an HCV RdRp inhibitor, could be repositioned to combat all three the epidemic/pandemic-causing HCoVs.

\section{Remdesivir as an Anti-HCoV Drug and Its Role in the Fight against COVID-19}

Remdesivir, also known as Gilead Science GS-5734 (16, Figure 4), is a phosphoramidate prodrug of the above-described nucleoside analog 11, which inhibits several families of viruses ranging from pneumoviruses, filoviruses, paramyxoviruses, and Ebola virus to human and zoonotic CoVs [130]. Owing to its mechanism of action (Figure 5), 16 intracellularly is presumed to undergo conversion to its triphosphate form 11a, which acts as a non-obligate chain terminator in viral RNA synthesis. In more detail, upon host cell entry, $\mathbf{1 6}$ is hydrolyzed by enzymes carboxylesterase 1 (CES1) and cathepsin A (CTSA) to a carboxylate form followed by loss of the phenoxide moiety to yield the derived alanine metabolite 16a (Figure 5) [148].

This metabolite subsequently undergoes hydrolysis to the monophosphate form $\mathbf{1 6 b}$, which is in turn hydrolyzed to GS-441524 (11) or phosphorylated by cellular kinases leading to the triphosphate form (11a) active in RdRp inhibition (Figure 5).

Remdesivir acts as a potent inhibitor of replication of MERS-CoV and SARS-CoV-1 in multiple in vitro models. Moreover, in animal studies, $\mathbf{1 6}$ displayed protective effects on mice infected with SARS-CoV-1 [149]. Since $\mathbf{1 6}$ had previously shown promise in the managing of socially-relevant viral diseases, and following the previously-emerged clues of efficacy also against $\mathrm{HCoVs}$, this drug was also early considered for COVID-19 therapy. FDA granted its emergency use authorization as an investigational drug for the treatment of COVID-19 on 1 May 2020 [150]. The encouraging results that came from randomized controlled trials led the same agency to approve on 22 October 2020 the administration of 16 (under the brand name Veklury) to 12 years of age and older COVID-19 patients for the 
treatment of the SARS-CoV-2-associated disease [82]. After that date, different meta-data analyses were published based on results from several clinical trials investigating the drug's role in COVID-19 therapy, confirming at least partially the initial enthusiasm for this antiviral treatment. Primary outcomes taken into consideration in these data-analyses were the recovery and mortality rates, while secondary ones were the drug safety profile. One of these studies [151], based on one observational study and four clinical trials, showed that the recovery rate on day 14 among severe COVID-19 patients treated with $\mathbf{1 6}$ for ten days increased by $50 \%$, while a $14 \%$ increase was recorded on day 28 among the moderate and severe group [151]. Moreover, the mortality rate on day 14, but not on day 28, was found decreased by $36 \%$ among all the remdesivir-receiving patients. Both responses to drug and mortality rates were more favorable in nonmechanically ventilated patients. Another metaanalysis study [152] compared COVID-19 patients receiving 10-day remdesivir treatment with placebo/standard of care groups, showing that the drug significantly reduced not only the 14-day mortality but also the requirement for mechanical ventilation, as well as severe adverse effects. Other indicators such as clinical improvement on day 28, day 14 clinical recovery, and day 14 discharge rate were found significantly more favorable in the same study among the remdesivir-receiving group. Earlier clinical improvement and recovery were observed among the patients who received 16. When comparing 10-day and 5 -day courses of $\mathbf{1 6}$, the longer course was accompanied by a higher discharge rate at day 14 and higher rates of serious adverse effects [152].

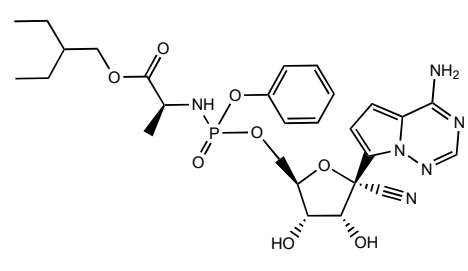

remdesivir

16
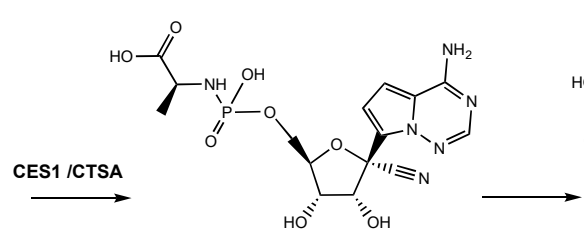

$16 a$

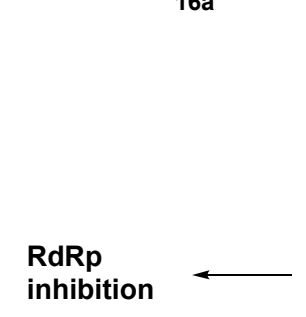

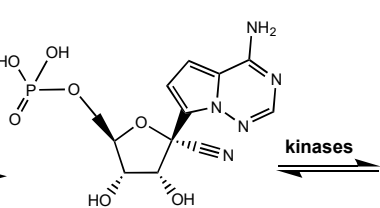

$16 b$

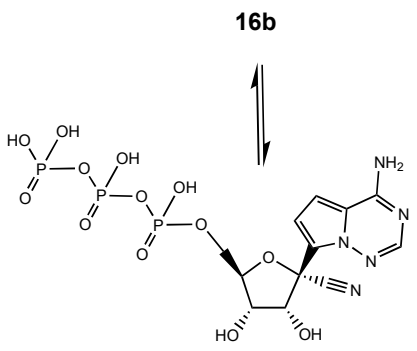

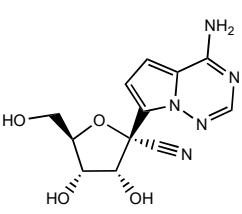

GS-441524

11

\section{GS-441524 triphosphate}

11a

Figure 5. Mechanism of the RdRp inhibitory activity of remdesivir and its non-phosphorylated nucleoside form GS-441524.

\section{Remdesivir Adverse Side Effects}

Although remdesivir has shown promise as a treatment for COVID-19, recent studies have raised concerns about potential adverse drug effects. In general, the more adverse outcome is observed in a longer course of the drug [152], but these are generally no significant grade III or IV adverse effects [151].

Apart from the more common low-grade side effects occurring during or soon after the time of drug infusion (such as low blood pressure, nausea, vomiting, and sweating [153]), marked sinus bradycardia, occurring acutely on the initiation of drug therapy and resolving almost immediately on its cessation, was reported [154]. An accurate study on the adverse drug events (ADEs) associated with remdesivir administration to COVID-19 patients analyzed 439 cases that reported 1004 adverse effects [155]. These ADEs, classified as severe in more than $80 \%$ of cases, were mainly from male patients older than 45 and corresponded mostly to: rise in hepatic enzyme levels, kidney injury, increased creatinine levels, and respiratory failure [155]. Overall, deterioration of hepatic, renal, and, less frequently, cardiac 
function were observed as ADEs associated with remdesivir administration, highlighting the need to monitor remdesivir-receiving patients for these ADEs carefully.

\section{Conclusions}

In this review, we summarized the most relevant literature regarding the development of nucleoside precursors and analogs as treatments for coronaviruses infections, with particular attention paid to the most pathogenic SARS-CoV-1, MERS-CoV, and especially SARS-CoV-2, which is at the origin of the current COVID-19 pandemic. We found that one of the main effects on the $\mathrm{HCoV}$ life cycle provoked by both classes of molecules is the competitive inhibition of the RdRp-mediated viral RNA synthesis. The triphosphate form of nucleoside derivatives is incorporated by RdRp, preventing the incorporation of additional nucleotides. In contrast, nucleoside precursors are initially converted into their ribonucleotide forms that successively undergo the same fate (Figure 2).

The low overall human-to-human transmission potential of MERS [156] and the disappearance of SARS in 2004 [74] may explain the low scientific interest paid to discover effective prophylactic and therapeutic weapons against $\mathrm{HCoVs}$ before the current COVID-19 era. This gap became evident when in late 2019 SARS-CoV-2 emerged in Wuhan, causing what eventually revealed the current pandemic. The urgent demand for an effective anti-COVID-19 therapy led to examining 'old drugs' already in use for other pathology treatments, whose safety profile had already been assessed. Among the several repurposed drugs under investigation against SARS-CoV-2, nucleoside analogs lately conquered a central role. Of these, the uridine monophosphate analog sofosbuvir, the modified cytidine molnupiravir, the adenosine analog GS-441524, and its monophosphate prodrug remdesivir showed encouraging results, justifying the recent FDA approval of this latter drug as the only specific anti-COVID-19 therapeutic agent available to date [82]. Even though remdesivir can be safely administered to hospitalized COVID-19 patients, it shows its optimal effect on those who are severely affected but not mechanically ventilated [151], leaving still unsolved the issue of treating the other cases by a specific anti-SARS-CoV-2 therapeutic agent. In our opinion, this gap could be mitigated through systematically evaluating the anti-COVID-19 effects of other nucleoside analogs or nucleoside precursors, including those listed in this review, for most of which only predictive studies, and no experimental data, on their ability to inhibit SARS-CoV-2 are available to date. As with SARS-CoV-1, MERS-CoV, and SARS-CoV-2, in the future, new zoonotic CoVs will likely be released from the heterogeneous virus pools present in animal reservoirs, and this could lead to future global threats. Therefore, it is fundamental to develop new broad-spectrum anti-HCoV prophylactic and therapeutic strategies aimed at multiple biomolecular targets and functions conserved across the HCoVs. More research into nucleoside/nucleoside precursor development, also starting from new synthetic structures, as well as their evaluation as $\mathrm{HCoV}$ antivirals, is urgently needed, and the scientific research in this field should not be interrupted when, hopefully soon, the current pandemic will be over.

Author Contributions: All authors contributed equally to the literature collection, writing, editing, and reviewing of the article. All authors have read and agreed to the published version of the manuscript.

Funding: This research received no external funding.

Conflicts of Interest: The authors declare no conflict of interest.

\section{References}

1. V'kovski, P.; Kratzel, A.; Steiner, S.; Stalder, H.; Thiel, V. Coronavirus biology and replication: Implications for SARS-CoV-2. Nat. Rev. Microbiol. 2020. [CrossRef]

2. Chu, D.K.W.; Leung, C.Y.H.; Gilbert, M.; Joyner, P.H.; Ng, E.M.; Tse, T.M.; Guan, Y.; Peiris, J.S.M.; Poon, L.L.M. Avian Coronavirus in Wild Aquatic Birds. J. Virol. 2011, 85, 12815-12820. [CrossRef]

3. Poon, L.L.M.; Chu, D.K.W.; Chan, K.H.; Wong, O.K.; Ellis, T.M.; Leung, Y.H.C.; Lau, S.K.P.; Woo, P.C.Y.; Suen, K.Y.; Yuen, K.Y.; et al. Identification of a Novel Coronavirus in Bats. J. Virol. 2005, 79, 2001-2009. [CrossRef] 
4. Wang, L.-F.; Anderson, D.E. Viruses in bats and potential spillover to animals and humans. Curr. Opin. Virol. 2019, 34, 79-89. [CrossRef] [PubMed]

5. Memish, Z.A.; Mishra, N.; Olival, K.J.; Fagbo, S.F.; Kapoor, V.; Epstein, J.H.; AlHakeem, R.; Durosinloun, A.; Al Asmari, M.; Islam, A.; et al. Middle East Respiratory Syndrome Coronavirus in Bats, Saudi Arabia. Emerg. Infect. Dis. 2013, 19, 1819-1823. [CrossRef]

6. Hofmann, H.; Pyrc, K.; van der Hoek, L.; Geier, M.; Berkhout, B.; Pohlmann, S. Human coronavirus NL63 employs the severe acute respiratory syndrome coronavirus receptor for cellular entry. Proc. Natl. Acad. Sci. USA 2005, 102, 7988-7993. [CrossRef] [PubMed]

7. Gossner, C.; Danielson, N.; Gervelmeyer, A.; Berthe, F.; Faye, B.; Kaasik Aaslav, K.; Adlhoch, C.; Zeller, H.; Penttinen, P.; Coulombier, D. Human-Dromedary Camel Interactions and the Risk of Acquiring Zoonotic Middle East Respiratory Syndrome Coronavirus Infection. Zoonoses Public Health 2014, 63, 1-9. [CrossRef] [PubMed]

8. Sheahan, T.; Rockx, B.; Donaldson, E.; Sims, A.; Pickles, R.; Corti, D.; Baric, R. Mechanisms of Zoonotic Severe Acute Respiratory Syndrome Coronavirus Host Range Expansion in Human Airway Epithelium. J. Virol. 2008, 82, 2274-2285. [CrossRef]

9. Sheahan, T.; Rockx, B.; Donaldson, E.; Corti, D.; Baric, R. Pathways of Cross-Species Transmission of Synthetically Reconstructed Zoonotic Severe Acute Respiratory Syndrome Coronavirus. J. Virol. 2008, 82, 8721-8732. [CrossRef] [PubMed]

10. Gaunt, E.R.; Hardie, A.; Claas, E.C.J.; Simmonds, P.; Templeton, K.E. Epidemiology and Clinical Presentations of the Four Human Coronaviruses 229E, HKU1, NL63, and OC43 Detected over 3 Years Using a Novel Multiplex Real-Time PCR Method. J. Clin. Microbiol. 2010, 48, 2940-2947. [CrossRef]

11. Woldemeskel, B.A.; Kwaa, A.K.; Garliss, C.C.; Laeyendecker, O.; Ray, S.C.; Blankson, J.N. Healthy donor T cell responses to common cold coronaviruses and SARS-CoV-2. J. Clin. Investig. 2020, 130, 6631-6638. [CrossRef]

12. Cevik, M.; Tate, M.; Lloyd, O.; Maraolo, A.E.; Schafers, J.; Ho, A. SARS-CoV-2, SARS-CoV-1 and MERS-CoV Viral Load Dynamics, Duration of Viral Shedding and Infectiousness: A Systematic Review and Meta-Analysis. Lancet Microbe 2020, 2, e13-e22. [CrossRef]

13. Andersen, K.G.; Rambaut, A.; Lipkin, W.I.; Holmes, E.C.; Garry, R.F. The proximal origin of SARS-CoV-2. Nat. Med. 2020, 26, 450-452. [CrossRef]

14. Rabaan, A.A.; Al-Ahmed, S.H.; Haque, S.; Sah, R.; Tiwari, R.; Malik, Y.S.; Dhama, K.; Yatoo, M.I.; Bonilla-Aldana, D.K.; Rodriguez-Morales, A.J. SARS-CoV-2, SARS-CoV, and MERS-COV: A comparative overview. Infez. Med. 2020, 28, $174-184$.

15. Peeri, N.C.; Shrestha, N.; Rahman, M.S.; Zaki, R.; Tan, Z.; Bibi, S.; Baghbanzadeh, M.; Aghamohammadi, N.; Zhang, W.; Haque, U. The SARS, MERS and novel coronavirus (COVID-19) epidemics, the newest and biggest global health threats: What lessons have we learned? Int. J. Epidemiol. 2020, 49, 717-726. [CrossRef] [PubMed]

16. Gordon, D.E.; Hiatt, J.; Bouhaddou, M.; Rezelj, V.V.; Ulferts, S.; Braberg, H.; Jureka, A.S.; Obernier, K.; Guo, J.Z.; Batra, J.; et al. Comparative host-coronavirus protein interaction networks reveal pan-viral disease mechanisms. Science 2020, 370 , eabe9403. [CrossRef] [PubMed]

17. Heurich, A.; Hofmann-Winkler, H.; Gierer, S.; Liepold, T.; Jahn, O.; Pohlmann, S. TMPRSS2 and ADAM17 Cleave ACE2 Differentially and Only Proteolysis by TMPRSS2 Augments Entry Driven by the Severe Acute Respiratory Syndrome Coronavirus Spike Protein. J. Virol. 2013, 88, 1293-1307. [CrossRef]

18. Belouzard, S.; Millet, J.K.; Licitra, B.N.; Whittaker, G.R. Mechanisms of Coronavirus Cell Entry Mediated by the Viral Spike Protein. Viruses 2012, 4, 1011-1033. [CrossRef] [PubMed]

19. Hulswit, R.J.G.; de Haan, C.A.M.; Bosch, B.J. Coronavirus Spike Protein and Tropism Changes. Adv. Virus Res. $2016,96,29-57$.

20. Kirchdoerfer, R.N.; Cottrell, C.A.; Wang, N.; Pallesen, J.; Yassine, H.M.; Turner, H.L.; Corbett, K.S.; Graham, B.S.; McLellan, J.S.; Ward, A.B. Pre-fusion structure of a human coronavirus spike protein. Nature 2016, 531, 118-121. [CrossRef]

21. Pillay, T.S. Gene of the month: The 2019-nCoV/SARS-CoV-2 novel coronavirus spike protein. J. Clin. Pathol. 2020, 73, 366-369. [CrossRef]

22. Xia, S.; Liu, M.; Wang, C.; Xu, W.; Lan, Q.; Feng, S.; Qi, F.; Bao, L.; Du, L.; Liu, S.; et al. Inhibition of SARS-CoV-2 (previously 2019-nCoV) infection by a highly potent pan-coronavirus fusion inhibitor targeting its spike protein that harbors a high capacity to mediate membrane fusion. Cell Res. 2020, 30, 343-355. [CrossRef]

23. Kim, C.-H. SARS-CoV-2 Evolutionary Adaptation toward Host Entry and Recognition of Receptor O-Acetyl Sialylation in Virus-Host Interaction. Int. J. Mol. Sci. 2020, 21, 4549. [CrossRef]

24. Artese, A.; Svicher, V.; Costa, G.; Salpini, R.; Di Maio, V.C.; Alkhatib, M.; Ambrosio, F.A.; Santoro, M.M.; Assaraf, Y.G.; Alcaro, S.; et al. Current status of antivirals and druggable targets of SARS CoV-2 and other human pathogenic coronaviruses. Drug Resist. Updates 2020, 53, 100721. [CrossRef]

25. Fehr, A.R.; Perlman, S. Coronaviruses: An Overview of Their Replication and Pathogenesis. Methods Mol Biol. $2015,1282,1-23$.

26. Chen, B.; Tian, E.-K.; He, B.; Tian, L.; Han, R.; Wang, S.; Xiang, Q.; Zhang, S.; El Arnaout, T.; Cheng, W. Overview of lethal human coronaviruses. Signal Transduct. Target. 2020, 5, 1-16. [CrossRef] [PubMed]

27. Cucinotta, D.; Vanelli, M. WHO Declares COVID-19 a Pandemic. Acta Biomed. 2020, 91, 157-160. [PubMed]

28. Mercatelli, D.; Holding, A.N.; Giorgi, F.M. Web tools to fight pandemics: The COVID-19 experience. Brief. Bioinform. 2020. [CrossRef] [PubMed]

29. Arthi, V.; Parman, J. Disease, downturns, and wellbeing: Economic history and the long-run impacts of COVID-19. Explor. Econ. Hist. 2020, 79, 101381-101400. [CrossRef] [PubMed] 
30. Roviello, V.; Roviello, G.N. Lower COVID-19 mortality in Italian forested areas suggests immunoprotection by Mediterranean plants. Env. Chem. Lett. 2020, 19, 699-710. [CrossRef]

31. Ibn-Mohammed, T.; Mustapha, K.B.; Godsell, J.; Adamu, Z.; Babatunde, K.A.; Akintade, D.D.; Acquaye, A.; Fujii, H.; Ndiaye, M.M.; Yamoah, F.A.; et al. A critical analysis of the impacts of COVID-19 on the global economy and ecosystems and opportunities for circular economy strategies. Resour. Conserv. Recycl. 2021, 164, 105169. [CrossRef]

32. Costanzo, M.; De Giglio, M.A.R.; Roviello, G.N. SARS CoV-2: Recent Reports on Antiviral Therapies Based on Lopinavir/Ritonavir, Darunavir/Umifenovir, Hydroxychloroquine, Remdesivir, Favipiravir and Other Drugs for the Treatment of the New Coronavirus. Curr. Med. Chem. 2020, 27, 4536-4541. [CrossRef]

33. Singh, T.U.; Parida, S.; Lingaraju, M.C.; Kesavan, M.; Kumar, D.; Singh, R.K. Drug repurposing approach to fight COVID-19. Pharm. Rep. 2020, 72, 1479-1508. [CrossRef] [PubMed]

34. Musumeci, D.; Roviello, V.; Roviello, G.N. DNA- and RNA-binding ability of oligoDapT, a nucleobase-decorated peptide, for biomedical applications. Int. J. Nanomed. 2018, 13, 2613-2629. [CrossRef]

35. Roviello, G.N.; Vicidomini, C.; Costanzo, V.; Roviello, V. Nucleic acid binding and other biomedical properties of artificial oligolysines. Int. J. Nanomed. 2016, 11, 5897-5904. [CrossRef]

36. Roviello, G.N. Novel insights into nucleoamino acids: Biomolecular recognition and aggregation studies of a thymine-conjugated 1-phenyl alanine. Amino Acids 2018, 50, 933-941. [CrossRef] [PubMed]

37. Musumeci, D.; Mokhir, A.; Roviello, G.N. Synthesis and nucleic acid binding evaluation of a thyminyl L-diaminobutanoic acid-based nucleopeptide. Bioorg. Chem. 2020, 100, 103862. [CrossRef]

38. Roviello, G.N.; Benedetti, E.; Pedone, C.; Bucci, E.M. Nucleobase-containing peptides: An overview of their characteristic features and applications. Amino Acids 2010, 39, 45-57. [CrossRef] [PubMed]

39. Roviello, G.N.; Musumeci, D. Synthetic approaches to nucleopeptides containing all four nucleobases, and nucleic acid-binding studies on a mixed-sequence nucleo-oligolysine. RSC Adv 2016, 6, 63578-63585. [CrossRef]

40. Roviello, G.N.; Musumeci, D.; Moccia, M.; Castiglione, M.; Sapio, R.; Valente, M.; Bucci, E.M.; Perretta, G.; Pedone, C. dabPNA Design, synthesis, and DNA binding studies. Ncleosides Nucleotides Nucleic Acids 2007, 26, 1307-1310. [CrossRef] [PubMed]

41. Oliviero, G.; Amato, J.; Borbone, N.; D’Errico, S.; Piccialli, G.; Bucci, E.; Piccialli, V.; Mayol, L. Synthesis of 4-N-alkyl and ribose-modified AICAR analogs on solid support. Tetrahedron 2008, 64, 6475-6481. [CrossRef]

42. Oliviero, G.; Amato, J.; Borbone, N.; D’Errico, S.; Piccialli, G.; Mayol, L. Synthesis of N-1 and ribose modified inosine analogs on solid support. Tetrahedron Lett. 2007, 48,397-400. [CrossRef]

43. Oliviero, G.; D’Errico, S.; Borbone, N.; Amato, J.; Piccialli, V.; Varra, M.; Piccialli, G.; Mayol, L. A solid-phase approach to the synthesis of N-1-alkyl analogs of cyclic inosine-diphosphate-ribose (cIDPR). Tetrahedron 2010, 66, 1931-1936. [CrossRef]

44. D’Errico, S.; Oliviero, G.; Amato, J.; Borbone, N.; Cerullo, V.; Hemminki, A.; Piccialli, V.; Zaccaria, S.; Mayol, L.; Piccialli, G. Synthesis and biological evaluation of unprecedented ring-expanded nucleosides (RENs) containing the imidazo[4,5d] $[1,2,6]$ oxadiazepine ring system. Chem. Commun. 2012, 48, 9310. [CrossRef]

45. Oliviero, G.; D’Errico, S.; Borbone, N.; Amato, J.; Piccialli, V.; Piccialli, G.; Mayol, L. Facile Solid-Phase Synthesis of AICAR 5'-Monophosphate (ZMP) and Its 4-N-Alkyl Derivatives. Eur. J. Org. Chem. 2010, 2010, 1517-1524. [CrossRef]

46. D’Errico, S.; Oliviero, G.; Borbone, N.; Amato, J.; D'Alonzo, D.; Piccialli, V.; Mayol, L.; Piccialli, G. A Facile Synthesis of 5'-Fluoro-5'-deoxyacadesine (5'-F-AICAR): A Novel Non-phosphorylable AICAR Analog. Molecules 2012, 17, 13036-13044. [CrossRef]

47. Roviello, G.N.; Gaetano, S.D.; Capasso, D.; Cesarani, A.; Bucci, E.M.; Pedone, C. Synthesis, spectroscopic studies and biological activity of a novel nucleopeptide with Moloney murine leukemia virus reverse transcriptase inhibitory activity. Amino Acids 2009, 38, 1489-1496. [CrossRef]

48. Roviello, G.N.; Di Gaetano, S.; Capasso, D.; Franco, S.; Crescenzo, C.; Bucci, E.M.; Pedone, C. RNA-Binding and Viral Reverse Transcriptase Inhibitory Activity of a Novel Cationic Diamino Acid-Based Peptide. J. Med. Chem. 2011, 54, 2095-2101. [CrossRef] [PubMed]

49. Seley-Radtke, K.L.; Yates, M.K. The evolution of nucleoside analog antivirals: A review for chemists and non-chemists. Part 1: Early structural modifications to the nucleoside scaffold. Antivir. Res. 2018, 154, 66-86. [CrossRef] [PubMed]

50. Eyer, L.; Nencka, R.; de Clercq, E.; Seley-Radtke, K.; Růžek, D. Nucleoside analogs as a rich source of antiviral agents active against arthropod-borne flaviviruses. Antivir. Chem. Chemother. 2018, 26, 204020661876129. [CrossRef]

51. Menéndez-Arias, L.; Jin, Z.; Smith, L.K.; Rajwanshi, V.K.; Kim, B.; Deval, J. The Ambiguous Base-Pairing and High Substrate Efficiency of T-705 (Favipiravir) Ribofuranosyl 5'-Triphosphate towards Influenza A Virus Polymerase. PLoS ONE 2013, 8, e68347.

52. Jin, Z.; Tucker, K.; Lin, X.; Kao, C.C.; Shaw, K.; Tan, H.; Symons, J.; Behera, I.; Rajwanshi, V.K.; Dyatkina, N.; et al. Biochemical Evaluation of the Inhibition Properties of Favipiravir and 2'-C-Methyl-Cytidine Triphosphates against Human and Mouse Norovirus RNA Polymerases. Antimicrob. Agents Chemother. 2015, 59, 7504-7516. [CrossRef] [PubMed]

53. Boretti, A. Favipiravir use for SARS CoV-2 infection. Pharm. Rep. 2020, 72, 1542-1552. [CrossRef] [PubMed]

54. Kaptein, S.J.F.; Jacobs, S.; Langendries, L.; Seldeslachts, L.; ter Horst, S.; Liesenborghs, L.; Hens, B.; Vergote, V.; Heylen, E.; Barthelemy, K.; et al. Favipiravir at high doses has potent antiviral activity in SARS-CoV-2-infected hamsters, whereas hydroxychloroquine lacks activity. Proc. Natl. Acad. Sci. USA 2020, 117, 26955-26965. [CrossRef] [PubMed]

55. Ye, Z.-W.; Yuan, S.; Yuen, K.-S.; Fung, S.-Y.; Chan, C.-P.; Jin, D.-Y. Zoonotic origins of human coronaviruses. Int. J. Biol. Sci. 2020, 16, 1686-1697. [CrossRef] 
56. Palù, G.; Parolin, C.; Calistri, A.; Salata, C. Coronaviruses: A paradigm of new emerging zoonotic diseases. Pathog. Dis. 2020, 77, ftaa006. [CrossRef]

57. Dijkman, R.; Jebbink, M.F.; El Idrissi, N.B.; Pyrc, K.; Muller, M.A.; Kuijpers, T.W.; Zaaijer, H.L.; van der Hoek, L. Human Coronavirus NL63 and 229E Seroconversion in Children. J. Clin. Microbiol. 2008, 46, 2368-2373. [CrossRef] [PubMed]

58. Sastre, P.; Dijkman, R.; Camuñas, A.; Ruiz, T.; Jebbink, M.F.; van der Hoek, L.; Vela, C.; Rueda, P. Differentiation between Human Coronaviruses NL63 and 229E Using a Novel Double-Antibody Sandwich Enzyme-Linked Immunosorbent Assay Based on Specific Monoclonal Antibodies. Clin. Vaccine Immunol. 2011, 18, 113-118. [CrossRef] [PubMed]

59. Al-Khannaq, M.N.; Ng, K.T.; Oong, X.Y.; Pang, Y.K.; Takebe, Y.; Chook, J.B.; Hanafi, N.S.; Kamarulzaman, A.; Tee, K.K. Molecular epidemiology and evolutionary histories of human coronavirus OC43 and HKU1 among patients with upper respiratory tract infections in Kuala Lumpur, Malaysia. Virol. J. 2016, 13, 1-12. [CrossRef]

60. Liu, D.X.; Liang, J.Q.; Fung, T.S. Human Coronavirus-229E, -OC43, -NL63, and -HKU1. Ref. Mod. Life Sci. 2020. [CrossRef]

61. Pene, F.; Merlat, A.; Vabret, A.; Rozenberg, F.; Buzyn, A.; Dreyfus, F.; Cariou, A.; Freymuth, F.; Lebon, P. Coronavirus 229E-Related Pneumonia in Immunocompromised Patients. Clin. Infect. Dis. 2003, 37, 929-932. [CrossRef] [PubMed]

62. Jordan, P.C.; Stevens, S.K.; Deval, J. Nucleosides for the treatment of respiratory RNA virus infections. Antivir. Chem. Chemother. 2018, 26, 204020661876448. [CrossRef]

63. Abdul-Rasool, S.; Fielding, B.C. Understanding Human Coronavirus HCoV-NL63. Open Virol. J. 2010, 4, 76-84. [CrossRef]

64. Esper, F.; Weibel, C.; Ferguson, D.; Landry, M.L.; Kahn, J.S. Coronavirus HKU1 Infection in the United States. Emerg. Infect. Dis. 2006, 12, 775-779. [CrossRef]

65. Hung, L.S. The SARS epidemic in Hong Kong: What lessons have we learned? JRSM 2003, 96, 374-378. [CrossRef]

66. Centers for Disease Control and Prevention. Outbreak of severe acute respiratory syndrome-Worldwide, 2003. MMWR Morb. Mortal. Wkly. Rep. 2003, 52, 226-228.

67. Centers for Disease Control and Prevention. In the Absence of SARS-CoV Transmission Worldwide: Guidance for Surveillance, Clinical and Laboratory Evaluation, and Reporting; Version 2; CDC: Atlanta, GA, USA, 2005.

68. World Health Organization. Middle East Respiratory Syndrome Coronavirus (MERS-CoV); WHO: Geneva, Switzerland, 2019.

69. Oboho, I.K.; Tomczyk, S.M.; Al-Asmari, A.M.; Banjar, A.A.; Al-Mugti, H.; Aloraini, M.S.; Alkhaldi, K.Z.; Almohammadi, E.L.; Alraddadi, B.M.; Gerber, S.I.; et al. 2014 MERS-CoV Outbreak in Jeddah-A Link to Health Care Facilities. N. Engl. J. Med. 2015, 372, 846-854. [CrossRef]

70. Yi, Y.; Lagniton, P.N.P.; Ye, S.; Li, E.; Xu, R.-H. COVID-19: What has been learned and to be learned about the novel coronavirus disease. Int. J. Biol. Sci. 2020, 16, 1753-1766. [CrossRef]

71. Sallard, E.; Halloy, J.; Casane, D.; van Helden, J.; Decroly, E. Tracing the origins of SARS-COV-2 in coronavirus phylogenies. Med. Sci (Paris) 2020, 36, 783-796. [CrossRef]

72. Lvov, D.K.; Alkhovsky, S.V. Source of the COVID-19 pandemic: Ecology and genetics of coronaviruses (Betacoronavirus: Coronaviridae) SARS-CoV, SARS-CoV-2 (subgenus Sarbecovirus), and MERS-CoV (subgenus Merbecovirus). Probl. Virol. Russ. J. 2020, 65, 62-70. [CrossRef] [PubMed]

73. Gaye, B.; Fanidi, A.; Jouven, X. Denominator matters in estimating COVID-19 mortality rates. Eur. Heart J. 2020, 41, 3500. [CrossRef]

74. Bolles, M.; Deming, D.; Long, K.; Agnihothram, S.; Whitmore, A.; Ferris, M.; Funkhouser, W.; Gralinski, L.; Totura, A.; Heise, M.; et al. A Double-Inactivated Severe Acute Respiratory Syndrome Coronavirus Vaccine Provides Incomplete Protection in Mice and Induces Increased Eosinophilic Proinflammatory Pulmonary Response upon Challenge. J. Virol. 2011, 85, 12201-12215. [CrossRef]

75. Khalili, J.S.; Zhu, H.; Mak, N.S.A.; Yan, Y.; Zhu, Y. Novel coronavirus treatment with ribavirin: Groundwork for an evaluation concerning COVID-19. J. Med. Virol. 2020, 92, 740-746. [CrossRef]

76. Chan, J.F.-W.; Yao, Y.; Yeung, M.-L.; Deng, W.; Bao, L.; Jia, L.; Li, F.; Xiao, C.; Gao, H.; Yu, P.; et al. Treatment with Lopinavir/Ritonavir or Interferon- $\beta 1 \mathrm{~b}$ Improves Outcome of MERS-CoV Infection in a Nonhuman Primate Model of Common Marmoset. J. Infect. Dis. 2015, 212, 1904-1913. [CrossRef]

77. Polack, F.P.; Thomas, S.J.; Kitchin, N.; Absalon, J.; Gurtman, A.; Lockhart, S.; Perez, J.L.; Pérez Marc, G.; Moreira, E.D.; Zerbini, C. Safety and efficacy of the BNT162b2 mRNA Covid-19 vaccine. N. Engl. J. Med. 2020, 383, 2603-2615. [CrossRef]

78. Baden, L.R.; El Sahly, H.M.; Essink, B.; Kotloff, K.; Frey, S.; Novak, R.; Diemert, D.; Spector, S.A.; Rouphael, N.; Creech, C.B. Efficacy and safety of the mRNA-1273 SARS-CoV-2 vaccine. N. Engl. J. Med. 2020. [CrossRef]

79. Voysey, M.; Clemens, S.A.C.; Madhi, S.A.; Weckx, L.Y.; Folegatti, P.M.; Aley, P.K.; Angus, B.; Baillie, V.L.; Barnabas, S.L.; Bhorat, Q.E. Safety and efficacy of the ChAdOx1 nCoV-19 vaccine (AZD1222) against SARS-CoV-2: An interim analysis of four randomised controlled trials in Brazil, South Africa, and the UK. Lancet 2020, 397, 99-111. [CrossRef]

80. Parker, E.P.; Shrotri, M.; Kampmann, B. Keeping track of the SARS-CoV-2 vaccine pipeline. Nat. Rev. Immunol. 2020, 20, 650. [CrossRef]

81. Hu, B.; Guo, H.; Zhou, P.; Shi, Z.-L. Characteristics of SARS-CoV-2 and COVID-19. Nat. Rev. Microbiol. 2020. [CrossRef]

82. Twomey, J.D.; Luo, S.; Dean, A.Q.; Bozza, W.P.; Nalli, A.; Zhang, B. COVID-19 update: The race to therapeutic development. Drug Resist. Updates 2020, 53, 100733. [CrossRef]

83. Gao, Y.; Yan, L.; Huang, Y.; Liu, F.; Zhao, Y.; Cao, L.; Wang, T.; Sun, Q.; Ming, Z.; Zhang, L. Structure of the RNA-dependent RNA polymerase from COVID-19 virus. Science 2020, 368, 779-782. [CrossRef] 
84. Zhu, W.; Chen, C.Z.; Gorshkov, K.; Xu, M.; Lo, D.C.; Zheng, W. RNA-dependent RNA polymerase as a target for COVID-19 drug discovery. Slas Discov. Adv. Sci. Drug Discov. 2020, 25, 1141-1151. [CrossRef] [PubMed]

85. Imbert, I.; Guillemot, J.C.; Bourhis, J.M.; Bussetta, C.; Coutard, B.; Egloff, M.P.; Ferron, F.; Gorbalenya, A.E.; Canard, B. A second, non-canonical RNA-dependent RNA polymerase in SARS Coronavirus. EMBO J. 2006, 25, 4933-4942. [CrossRef]

86. Min, J.S.; Kim, G.-W.; Kwon, S.; Jin, Y.-H. A Cell-Based Reporter Assay for Screening Inhibitors of MERS Coronavirus RNADependent RNA Polymerase Activity. J. Clin. Med. 2020, 9, 2399. [CrossRef] [PubMed]

87. Lu, A.; Zhang, H.; Zhang, X.; Wang, H.; Hu, Q.; Shen, L.; Schaffhausen, B.S.; Hou, W.; Li, L. Attenuation of SARS coronavirus by a short hairpin RNA expression plasmid targeting RNA-dependent RNA polymerase. Virology 2004, 324, 84-89. [CrossRef]

88. Mielech, A.M.; Kilianski, A.; Baez-Santos, Y.M.; Mesecar, A.D.; Baker, S.C. MERS-CoV papain-like protease has deISGylating and deubiquitinating activities. Virology 2014, 450, 64-70. [CrossRef]

89. Klemm, T.; Ebert, G.; Calleja, D.J.; Allison, C.C.; Richardson, L.W.; Bernardini, J.P.; Lu, B.G.; Kuchel, N.W.; Grohmann, C.; Shibata, Y. Mechanism and inhibition of the papain-like protease, PLpro, of SARS-CoV-2. EMBO J. 2020, 39, e106275. [CrossRef]

90. Dai, W.; Zhang, B.; Jiang, X.-M.; Su, H.; Li, J.; Zhao, Y.; Xie, X.; Jin, Z.; Peng, J.; Liu, F. Structure-based design of antiviral drug candidates targeting the SARS-CoV-2 main protease. Science 2020, 368, 1331-1335. [CrossRef]

91. Hilgenfeld, R. From SARS to MERS: Crystallographic studies on coronaviral proteases enable antiviral drug design. 2014, 281, 4085-4096. [CrossRef] [PubMed]

92. Sharma, P.; Vijayan, V.; Pant, P.; Sharma, M.; Vikram, N.; Kaur, P.; Singh, T.; Sharma, S. Identification of potential drug candidates to combat COVID-19: A structural study using the main protease (mpro) of SARS-CoV-2. J. Biomol. Struct. Dyn. 2020, 1-11. [CrossRef]

93. Chu, C.; Cheng, V.; Hung, I.; Wong, M.; Chan, K.; Chan, K.; Kao, R.; Poon, L.; Wong, C.; Guan, Y. Role of lopinavir/ritonavir in the treatment of SARS: Initial virological and clinical findings. Thorax 2004, 59, 252-256. [CrossRef] [PubMed]

94. Cao, B.; Wang, Y.; Wen, D.; Liu, W.; Wang, J.; Fan, G.; Ruan, L.; Song, B.; Cai, Y.; Wei, M. A trial of lopinavir-ritonavir in adults hospitalized with severe Covid-19. N. Engl. J. Med. 2020. [CrossRef]

95. Wang, Y.; Anirudhan, V.; Du, R.; Cui, Q.; Rong, L. RNA-dependent RNA polymerase of SARS-CoV-2 as a therapeutic target. J. Med. Virol. 2020. [CrossRef]

96. Furuta, Y.; Gowen, B.B.; Takahashi, K.; Shiraki, K.; Smee, D.F.; Barnard, D.L. Favipiravir (T-705), a novel viral RNA polymerase inhibitor. Antivir. Res. 2013, 100, 446-454. [CrossRef]

97. Kiso, M.; Takahashi, K.; Sakai-Tagawa, Y.; Shinya, K.; Sakabe, S.; Le, Q.M.; Ozawa, M.; Furuta, Y.; Kawaoka, Y. T-705 (favipiravir) activity against lethal H5N1 influenza A viruses. Proc. Natl. Acad. Sci. USA 2010, 107, 882-887. [CrossRef]

98. Smither, S.J.; Eastaugh, L.S.; Steward, J.A.; Nelson, M.; Lenk, R.P.; Lever, M.S. Post-exposure efficacy of oral T-705 (Favipiravir) against inhalational Ebola virus infection in a mouse model. Antivir. Res. 2014, 104, 153-155. [CrossRef] [PubMed]

99. Ivashchenko, A.A.; Dmitriev, K.A.; Vostokova, N.V.; Azarova, V.N.; Blinow, A.A.; Egorova, A.N.; Gordeev, I.G.; Ilin, A.P.; Karapetian, R.N.; Kravchenko, D.V.; et al. AVIFAVIR for Treatment of Patients With Moderate Coronavirus Disease 2019 (COVID-19): Interim Results of a Phase II/III Multicenter Randomized Clinical Trial. Clin. Infect. Dis. 2020. [CrossRef]

100. Takahashi, H.; Iwasaki, Y.; Watanabe, T.; Ichinose, N.; Okada, Y.; Oiwa, A.; Kobayashi, T.; Moriya, M.; Oda, T. Case studies of SARS-CoV-2 treated with favipiravir among patients in critical or severe condition. Int. J. Infect. Dis. 2020, 100, 283-285. [CrossRef] [PubMed]

101. Delang, L.; Abdelnabi, R.; Neyts, J. Favipiravir as a potential countermeasure against neglected and emerging RNA viruses. Antivir. Res. 2018, 153, 85-94. [CrossRef] [PubMed]

102. Moorhouse, P.C.; Grootveld, M.; Halliwell, B.; Quinlan, J.G.; Gutteridge, J.M. Allopurinol and oxypurinol are hydroxyl radical scavengers. FEBS Lett. 1987, 213, 23-28. [CrossRef]

103. Escobar, J.; Pereda, J.; Arduini, A.; Sandoval, J.; Moreno, M.L.; Pérez, S.; Sabater, L.; Aparisi, L.; Cassinello, N.; Hidalgo, J.; et al. Oxidative and nitrosative stress in acute pancreatitis. Modulation by pentoxifylline and oxypurinol. Biochem. Pharm. 2012, 83, 122-130. [CrossRef]

104. Pereda, J.; Sabater, L.; Cassinello, N.; Gómez-Cambronero, L.; Closa, D.; Folch-Puy, E.; Aparisi, L.; Calvete, J.; Cerd, M.; Lled, S.; et al. Effect of Simultaneous Inhibition of TNF- $\alpha$ Production and Xanthine Oxidase in Experimental Acute Pancreatitis. Ann. Surg. 2004, 240, 108-116. [CrossRef] [PubMed]

105. López-Iranzo, F.J.; López-Rodas, A.M.; Franco, L.; López-Rodas, G. Pentoxifylline and Oxypurinol: Potential Drugs to Prevent the Cytokine Release (Storm) Syndrome Caused by SARS-CoV-2? Curr. Pharm. Des. 2020, 26, 4515-4521. [CrossRef] [PubMed]

106. Sullivan, G.; Carper, H.; Novick, W.; Mandell, G. Inhibition of the inflammatory action of interleukin-1 and tumor necrosis factor (alpha) on neutrophil function by pentoxifylline. Infect. Immun. 1988, 56, 1722-1729. [CrossRef]

107. Kunwar, S.; Collins, C.E.; Constantinescu, F. Baricitinib, a Janus kinase inhibitor, in the treatment of rheumatoid arthritis: A systematic literature review and meta-analysis of randomized controlled trials. Clin. Rheumatol. 2018, 37, 2611-2620. [CrossRef] [PubMed]

108. Favalli, E.G.; Biggioggero, M.; Maioli, G.; Caporali, R. Baricitinib for COVID-19: A suitable treatment? Lancet Infect. Dis. 2020. [CrossRef]

109. Mosow, J.A. Methotrexate transport and resistance. Leuk. Lymphoma 1998, 30, 215-224. [CrossRef] [PubMed]

110. Caruso, A.; Caccuri, F.; Bugatti, A.; Zani, A.; Vanoni, M.; Bonfanti, P.; Cazzaniga, M.E.; Perno, C.F.; Messa, C.; Alberghina, L. Methotrexate inhibits SARS-CoV-2 virus replication "in vitro". J. Med. Virol. 2020. [CrossRef] [PubMed] 
111. Deval, J. Antimicrobial Strategies. Drugs 2009, 69, 151-166. [CrossRef]

112. Arts, E.J.; Wainberg, M.A. Mechanisms of nucleoside analog antiviral activity and resistance during human immunodeficiency virus reverse transcription. Antimicrob. Agents Chemother. 1996, 40, 527. [CrossRef]

113. Pruijssers, A.J.; Denison, M.R. Nucleoside analogs for the treatment of coronavirus infections. Curr. Opin. Virol. 2019, 35, 57-62. [CrossRef]

114. Sheahan, T.P.; Sims, A.C.; Zhou, S.; Graham, R.L.; Pruijssers, A.J.; Agostini, M.L.; Leist, S.R.; Schäfer, A.; Dinnon, K.H.; Stevens, L.J.; et al. An orally bioavailable broad-spectrum antiviral inhibits SARS-CoV-2 in human airway epithelial cell cultures and multiple coronaviruses in mice. Sci. Transl. Med. 2020, 12, eabb5883. [CrossRef]

115. Barnard, D.L.; Hubbard, V.D.; Burton, J.; Smee, D.F.; Morrey, J.D.; Otto, M.J.; Sidwell, R.W. Inhibition of severe acute respiratory syndrome-associated coronavirus (SARSCoV) by calpain inhibitors and $\beta-\mathrm{D}-\mathrm{N} 4-$ hydroxycytidine. Antivir. Chem. Chemother. 2004, 15, 15-22. [CrossRef]

116. Agostini, M.L.; Pruijssers, A.J.; Chappell, J.D.; Gribble, J.; Lu, X.; Andres, E.L.; Bluemling, G.R.; Lockwood, M.A.; Sheahan, T.P.; Sims, A.C.; et al. Small-Molecule Antiviral $\beta$-D-N4-Hydroxycytidine Inhibits a Proofreading-Intact Coronavirus with a High Genetic Barrier to Resistance. J. Virol. 2019, 93. [CrossRef] [PubMed]

117. Toots, M.; Yoon, J.-J.; Cox, R.M.; Hart, M.; Sticher, Z.M.; Makhsous, N.; Plesker, R.; Barrena, A.H.; Reddy, P.G.; Mitchell, D.G. Characterization of orally efficacious influenza drug with high resistance barrier in ferrets and human airway epithelia. Sci. Transl. Med. 2019, 11. [CrossRef] [PubMed]

118. Cox, R.M.; Wolf, J.D.; Plemper, R.K. Therapeutically administered ribonucleoside analog MK-4482/EIDD-2801 blocks SARS-CoV-2 transmission in ferrets. Nat. Microbiol. 2020, 6, 1-8.

119. Corum, J.; Wu, K.J.; Zimmer, C. Coronavirus Drug and Treatment Tracker. New York Times 2020. Available online: http: //www.nomeofficinapolitica.it/wp-content/uploads/2020/10/Farmaci_NYT.pdf (accessed on 10 December 2020).

120. Shin, H.J.; Kim, C.; Cho, S. Gemcitabine and nucleos (t) ide synthesis inhibitors are broad-spectrum antiviral drugs that activate innate immunity. Viruses 2018, 10, 211. [CrossRef]

121. Zhang, Y.-N.; Zhang, Q.-Y.; Li, X.-D.; Xiong, J.; Xiao, S.-Q.; Wang, Z.; Zhang, Z.-R.; Deng, C.-L.; Yang, X.-L.; Wei, H.-P.; et al. Gemcitabine, lycorine and oxysophoridine inhibit novel coronavirus (SARS-CoV-2) in cell culture. Emerg. Microbes Infect. 2020, 9 , 1170-1173. [CrossRef]

122. Warren, T.; MacLennan, S.; Mathis, A.; Giuliano, E.; Taylor, R.; Sheridan, W. Efficacy of galidesivir against Ebola virus disease in rhesus monkeys. Open Forum Infect. Dis. 2017, 4, S302. [CrossRef]

123. Elfiky, A.A. SARS-CoV-2 RNA dependent RNA polymerase (RdRp) targeting: An in silico perspective. J. Biomol. Struct. Dyn. 2020. Published electronically May 6. [CrossRef]

124. Te, H.S.; Randall, G.; Jensen, D.M. Mechanism of action of ribavirin in the treatment of chronic hepatitis C. Gastroenterol. Hepatol. 2007, 3, 218.

125. Ventre, K.; Randolph, A. Ribavirin for respiratory syncytial virus infection of the lower respiratory tract in infants and young children. Cochrane Database Syst. Rev. 2007, 24, CD000181. [CrossRef]

126. Falzarano, D.; De Wit, E.; Rasmussen, A.L.; Feldmann, F.; Okumura, A.; Scott, D.P.; Brining, D.; Bushmaker, T.; Martellaro, C.; Baseler, L. Treatment with interferon- $\alpha 2 \mathrm{~b}$ and ribavirin improves outcome in MERS-CoV-infected rhesus macaques. Nat. Med. 2013, 19, 1313-1317. [CrossRef]

127. Cinatl, J.; Morgenstern, B.; Bauer, G.; Chandra, P.; Rabenau, H.; Doerr, H.W. Glycyrrhizin, an active component of liquorice roots, and replication of SARS-associated coronavirus. Lancet 2003, 361, 2045-2046. [CrossRef]

128. Pyrc, K.; Bosch, B.J.; Berkhout, B.; Jebbink, M.F.; Dijkman, R.; Rottier, P.; van der Hoek, L. Inhibition of Human Coronavirus NL63 Infection at Early Stages of the Replication Cycle. Antimicrob. Agents Chemother. 2006, 50, 2000-2008. [CrossRef]

129. Santos, I.D.A.; Grosche, V.R.; Bergamini, F.R.G.; Sabino-Silva, R.; Jardim, A.C.G. Antivirals Against Coronaviruses: Candidate Drugs for SARS-CoV-2 Treatment? Front. Microbiol. 2020, 11, 1818. [CrossRef] [PubMed]

130. Amirian, E.S.; Levy, J.K. Current knowledge about the antivirals remdesivir (GS-5734) and GS-441524 as therapeutic options for coronaviruses. One Health 2020, 9, 100128. [CrossRef]

131. Yan, V.; Muller, F. Comprehensive Summary Supporting Clinical Investigation of GS-441524 for Covid-19 Treatment. OSF Preprints. 2020. Available online: https://doi.org/10.31219/osf.io/mnhxu (accessed on 10 December 2020).

132. Yin, W.; Mao, C.; Luan, X.; Shen, D.-D.; Shen, Q.; Su, H.; Wang, X.; Zhou, F.; Zhao, W.; Gao, M.; et al. Structural basis for inhibition of the RNA-dependent RNA polymerase from SARS-CoV-2 by remdesivir. Science 2020, 368, 1499-1504. [CrossRef]

133. Sehnal, D.; Rose, A.; Koča, J.; Burley, S.; Velankar, S. Mol*: Towards a common library and tools for web molecular graphics. In MolVa: Workshop on Molecular Graphics and Visual Analysis of Molecular Data; Eurographics Association: Goslar, Germany, 2018.

134. Gan, L.; Seyedsayamdost, M.R.; Shuto, S.; Matsuda, A.; Petsko, G.A.; Hedstrom, L. The immunosuppressive agent mizoribine monophosphate forms a transition state analog complex with inosine monophosphate dehydrogenase. Biochemistry 2003, 42, 857-863. [CrossRef]

135. Saijo, M.; Morikawa, S.; Fukushi, S.; Mizutani, T.; Hasegawa, H.; Nagata, N.; Iwata, N.; Kurane, I. Inhibitory effect of mizoribine and ribavirin on the replication of severe acute respiratory syndrome (SARS)-associated coronavirus. Antivir. Res. 2005, 66, 159-163. [CrossRef]

136. Jakovac, H. COVID-19 and hypertension: Is the HSP60 culprit for the severe course and worse outcome? Am. J. Physiol. Heart Circ. Physiol. 2020, 319, H793-H796. [CrossRef] [PubMed] 
137. Peters, H.L.; Jochmans, D.; de Wilde, A.H.; Posthuma, C.C.; Snijder, E.J.; Neyts, J.; Seley-Radtke, K.L. Design, synthesis and evaluation of a series of acyclic fleximer nucleoside analogs with anti-coronavirus activity. Bioorg. Med. Chem. Lett. 2015, 25, 2923-2926. [CrossRef]

138. Jácome, R.; Campillo-Balderas, J.A.; de León, S.P.; Becerra, A.; Lazcano, A. Sofosbuvir as a potential alternative to treat the SARS-CoV-2 epidemic. Sci. Rep. 2020, 10, 1-5.

139. Li, G.; De Clercq, E. Therapeutic options for the 2019 novel coronavirus (2019-nCoV). Nat. Rev. Drug Discov. 2020, 19, 149-150. [CrossRef] [PubMed]

140. Elfiky, A.A. Ribavirin, Remdesivir, Sofosbuvir, Galidesivir, and Tenofovir against SARS-CoV-2 RNA dependent RNA polymerase (RdRp): A molecular docking study. Life Sci. 2020, 253, 117592. [CrossRef]

141. Chien, M.; Anderson, T.K.; Jockusch, S.; Tao, C.; Li, X.; Kumar, S.; Russo, J.J.; Kirchdoerfer, R.N.; Ju, J. Nucleotide analogs as inhibitors of SARS-CoV-2 polymerase, a key drug target for COVID-19. J. Proteome Res. 2020, 19, 4690-4697. [CrossRef]

142. Zandi, K.; Amblard, F.; Musall, K.; Downs-Bowen, J.; Kleinbard, R.; Oo, A.; Cao, D.; Liang, B.; Russell, O.O.; McBrayer, T.; et al. Repurposing Nucleoside Analogs for Human Coronaviruses. Antimicrob. Agents Chemother. 2020. [CrossRef]

143. Sadeghi, A.; Ali Asgari, A.; Norouzi, A.; Kheiri, Z.; Anushirvani, A.; Montazeri, M.; Hosamirudsai, H.; Afhami, S.; Akbarpour, E.; Aliannejad, R.; et al. Sofosbuvir and daclatasvir compared with standard of care in the Treat of patients admitted to hospital with moderate or severe coronavirus infection (COVID-19): A randomized controlled trial. J. Antimicrob. Chemother. 2020, 75, 3379-3385. [CrossRef]

144. Kutlu, O. Can Tenofovir diphosphate be a candidate drug for SARS-CoV-2? First clinical perspective. Int. J. Clin. Pr. 2020. [CrossRef]

145. Buonaguro, L.; Tagliamonte, M.; Tornesello, M.L.; Buonaguro, F.M. SARS-CoV-2 RNA polymerase as target for antiviral therapy. J. Transl. Med. 2020, 18. [CrossRef]

146. Picarazzi, F.; Vicenti, I.; Saladini, F.; Zazzi, M.; Mori, M. Targeting the RdRp of Emerging RNA Viruses: The Structure-Based Drug Design Challenge. Molecules 2020, 25, 5695. [CrossRef]

147. Elfiky, A.A.; Azzam, E.B. Novel guanosine derivatives against MERS CoV polymerase: An in silico perspective. J. Biomol. Struct. Dyn. 2020, 1-9. [CrossRef]

148. Eastman, R.T.; Roth, J.S.; Brimacombe, K.R.; Simeonov, A.; Shen, M.; Patnaik, S.; Hall, M.D. Remdesivir: A Review of Its Discovery and Development Leading to Emergency Use Authorization for Treatment of COVID-19. ACS Cent. Sci. 2020, 6, 672-683. [CrossRef]

149. Sheahan, T.P.; Sims, A.C.; Graham, R.L.; Menachery, V.D.; Gralinski, L.E.; Case, J.B.; Leist, S.R.; Pyrc, K.; Feng, J.Y.; Trantcheva, I.; et al. Broad-spectrum antiviral GS-5734 inhibits both epidemic and zoonotic coronaviruses. Sci. Transl. Med. 2017, 9, eaal3653. [CrossRef] [PubMed]

150. Choudhury, S.; Chakraborty, D.S.; Lahiry, S.; Chatterjee, S. Past, Present, and Future of Remdesivir: An Overview of the Antiviral in Recent Times. Indian J. Crit. Care Med. Peer Rev. Off. Publ. Indian Soc. Crit. Care Med. 2020, 24, 570.

151. Elsawah, H.K.; Elsokary, M.A.; Abdallah, M.S.; ElShafie, A.H. Efficacy and safety of remdesivir in hospitalized Covid-19 patients: Systematic review and meta-analysis including network meta-analysis. Rev. Med. Virol. 2020, e2187. [CrossRef]

152. Shrestha, D.B.; Budhathoki, P.; Syed, N.-I.-H.; Rawal, E.; Raut, S.; Khadka, S. Remdesivir: A potential game-changer or just a myth? A systematic review and meta-analysis. Life Sci. 2020, 264, 118663. [CrossRef]

153. Veronin, M.A.; Lang, A.; Reinert, J.P. Remdesivir and Coronavirus Disease 2019 (COVID-19): Essential Questions and Answers for Pharmacists and Pharmacy Technicians. J. Pharm. Technol. 2021, 37, 62-71. [CrossRef]

154. Gubitosa, J.C.; Kakar, P.; Gerula, C.; Nossa, H.; Finkel, D.; Wong, K.; Khatri, M.; Ali, H. Marked Sinus Bradycardia Associated With Remdesivir in COVID-19. JACC Case Rep. 2020, 2, 2260-2264. [CrossRef] [PubMed]

155. Charan, J.; Kaur, R.J.; Bhardwaj, P.; Haque, M.; Sharma, P.; Misra, S.; Godman, B. Rapid review of suspected adverse drug events due to remdesivir in the WHO database; findings and implications. Expert Rev. Clin. Pharm. 2020. [CrossRef]

156. Chowell, G.; Abdirizak, F.; Lee, S.; Lee, J.; Jung, E.; Nishiura, H.; Viboud, C. Transmission characteristics of MERS and SARS in the healthcare setting: A comparative study. BMC Med. 2015, 13, 1-12. [CrossRef] [PubMed] 